\title{
Aspirin and Analgesic Nephropathy
}

\author{
A. F. MACKLON, A. W. CRAFT, MALCOLM THOMPSON, DAVID N. S. KERR
}

British Medical fournal, 1974, 1, 597-600

\begin{abstract}
Summary
Renal function was studied in 17 patients with rheumatoid arthritis who had each consumed between 5 and 20 $\mathrm{kg}$ of aspirin. After an interval of two years 14 of these patients-seven of whom had consumed a further mean of $2 \mathrm{~kg}$ of aspirin- had their renal function retested. No relation was found between total dose, rate, or duration of ingestion and any aspect of renal function that was studied. All patients had plasma creatinine levels within the normal range, though slight depression in creatinine clearance was not uncommon.

From this study and other published data we conclude that aspirin rarely if ever causes analgesic nephropathy when prescribed alone in doses appropriate to the treatment of rheumatoid arthritis.
\end{abstract}

\section{Introduction}

Though a few investigations have failed to show any connexion between analgesic intake and renal disease (Lawson, 1973; Waters et al., 1973) most nephrologists accept analgesic nephropathy as an established entity (Abel, 1971; Burry, 1971; Clarkson and Lawrence, 1971; Gault et al., 1971; Murray et al., 1971; Kingsley et al., 1972; Linton, 1972; Wilson, 1972; CoveSmith and Knapp, 1973). In contrast to this near unanimity on the nature of the disease is a continuing dispute about its cause. After Spühler and Zollinger's (1953) description phenacetin emerged as the one common ingredient in the varied mixtures of analgesic, sedative, opiate, and stimulant drugs incriminated. Most workers regarded it as the major or only cause of the disease (see Lawson and Maclean, 1966; Shelley, 1967, for review). The epidemiological evidence has continued to impress some authors, who have retained the name "phenacetin" in their descriptions of the disease or recommended restrictions on the sale of the drug (Bell et al., 1969; Bengsston, 1969; Raaflaub and Dubach, 1969, 1972; Koutsaimanis and de Wardener, 1970; de Wardener and Koutsaimanis, 1971 ; Dubach, 1971 ; Sanerkin, 1971).

Phenacetin is not an indispensible drug; its withdrawal from one British hospital caused no regrets (Hart et al., 1970). In Sweden sales of phenacetin over the counter were banned in 1961 while aspirin and phenazone remained on free sale; the incidence of the disease fell (Bengsston, 1969; Nordenfelt, 1972). A similar decline in the incidence of analgesic nephropathy resulted from the replacement of phenacetin by other analgesics in proprietary mixtures popular in South West Scotland (Murray, 1972 a). Several other countries have restricted or discouraged the sale of phenacetin (Bishop et al., 1972).

\footnotetext{
Department of Rheumatology, Royal Victoria Infirmary, Newcastle upon Tyne

A. F. MACKLON, M.B., B.S., Research Fellow (Present appointment: Registrar, Department of Medicine, Royal Victoria Infirmary)

A. W. CRAFT, M.B., M.R.C.P., Senior House Officer (Present appointment: Registrar, Department of Child Health, Royal Victoria Infirmary) MALCOLM THOMPSON, M.D., F.R.C.P., Consultant Rheumatologist

Department of Medicine, University of Newcastle upon Tyne DAVID N. S. KERR, M.SC., F.R.C.P., Professor
}

On the other hand there is a strong body of opinion that phenacetin has been singled out prematurely (Gilman, 1964; Shelley, 1967; Gault et al., 1968; Prescott, 1969, 1970, 1971; Kincaid-Smith, 1970 a, b; Abel, 1971; Gault, 1972). It is rarely taken alone and many of the drugs with which it is commonly combined, or their metabolites, are nephrotoxic to some animals under some circumstances (Saker and Kincaid-Smith, 1969; Nanra and Kincaid-Smith, 1970; Calder et al., 1971, 1972; Nanra et al., 1971). Consequently "analgesic nephropathy" has replaced "phenacetin kidney" as the common title for the disease (British Medical fournal, 1965, 1970) and some workers regard other analgesics, particularly aspirin, with such grave suspicion that they call for restrictions on the sale of all common analgesics (Nanra et al., 1971). This would be a much greater curtailment of personal convenience than merely the withdrawal of a single drug, however, and rigid restrictions on the sale of aspirin would be particularly troublesome to rheumatologists (Scott, 1966), who often prescribe aspirin alone in total doses of many kilograms for the treatment of rheumatoid arthritis.

We therefore looked for evidence of chronic renal disease in patients attending a rheumatology clinic who had taken large quantities of aspirin without also taking appreciable quantities of any other drugs suspected of causing renal damage. We defined "heavy aspirin consumption" as a total intake of $5 \mathrm{~kg}$ or more since the patients in three reported series who developed analgesic nephropathy from aspirin-phenacetin mixtures had typically consumed at least this amount of aspirin (Gault et al., 1968 ; range 3-27 kg, mean $8 \mathrm{~kg}$ : Bell et al., 1969; range 2-12 kg, mean $6 \mathrm{~kg}$ : Murray et al., 1971; range $2-69 \mathrm{~kg}$, mean $17 \mathrm{~kg}$ ).

\section{Patients and Methods}

All patients attending the rheumatology clinic and seen by two of us (A.F.M. and A.W.C.) were questioned about drug consumption and their answers were checked against the case notes and information from their family doctor. Seventeen patients, 15 women and two men, all with classical rheumatoid arthritis by American Rheumatism Association criteria (Ropes et al., 1959), had taken more than $5 \mathrm{~kg}$ of aspirin and all were investigated since none had any appreciable intake of other potentially nephrotoxic drugs.

Since we intended to follow this group of patients we performed only those tests which could be carried out without discomfort or hospital admission. In every patient plasma urea, plasma creatinine, and 24-hour creatinine clearance were measured by standard AutoAnalyzer techniques. Proteinuria was sought by Albustix and white cell excretion rate in a fresh four-hour non-catheter urine sample concentrated by centrifugation was counted in a Fuchs-Rosenthal chamber. Intravenous pyelography was performed in five patients. Fourteen patients were reinvestigated after two years, during which seven of them had consumed an average of $2 \mathrm{~kg}$ of additional aspirin.

\section{Results}

Details of age, drug consumption, blood pressure, and renal function tests are shown in table I. Creatinine clearance was corrected for surface area and then converted into a percentage of the mean normal for the patients' age, estimated from the collected data of Wesson (1969). Among the original 17 patients correlations were sought between the plasma creatinine and the 
TABLE I-Aspirin Consumption and Results of Renal Function Tests in 17 Patients with Rheumatoid Arthritis

\begin{tabular}{|c|c|c|c|c|c|c|c|c|c|}
\hline \multirow{2}{*}{$\begin{array}{l}\text { Case } \\
\text { No. }\end{array}$} & \multirow{2}{*}{$\underset{(\mathrm{yr})}{\text { Age }}$} & \multirow{2}{*}{$\begin{array}{l}\text { Total Dose } \\
\text { of Aspirin } \\
(\mathbf{k g})\end{array}$} & \multirow{2}{*}{$\begin{array}{c}\text { Duration of } \\
\text { Consumption } \\
(y r)\end{array}$} & \multirow{2}{*}{$\begin{array}{c}\text { Overall Rate of } \\
\text { Consumption } \\
\text { (g/Day) }\end{array}$} & \multicolumn{2}{|c|}{$\begin{array}{c}\text { Blood Pressure } \\
\text { (mm Hg) }\end{array}$} & \multirow{2}{*}{$\underset{\text { Creatinine }}{\text { Plasma }}$} & \multirow{2}{*}{$\begin{array}{c}\text { Corrected } \\
\text { Creatinine } \\
\text { Clearance } \\
\left(\mathrm{ml} / \mathrm{min} / 1.73 \mathrm{~m}^{2}\right)\end{array}$} & \multirow{2}{*}{$\begin{array}{c}\text { W.B.C.Excretion } \\
\text { Rate } \\
\left(\times 10^{3} / \mathrm{hr}\right)\end{array}$} \\
\hline & & & & & Systolic & Diastolic & & & \\
\hline $\begin{array}{c}1 \\
2 \\
3 \\
4 \\
5 \\
6^{*} \\
7 \\
8 \\
9 \\
10 \\
11 \\
12 \\
13^{*} \\
14 \\
15 \\
16 \\
17\end{array}$ & $\begin{array}{l}42 \\
70 \\
62 \\
56 \\
34 \\
54 \\
50 \\
69 \\
67 \\
60 \\
26 \\
47 \\
55 \\
62 \\
65 \\
41 \\
68\end{array}$ & $\begin{array}{r}7.0 \\
7.0 \\
7.2 \\
7.6 \\
8.0 \\
8.3 \\
8.7 \\
10.0 \\
10.4 \\
11.4 \\
11.6 \\
12.2 \\
12.2 \\
13.0 \\
14.8 \\
15.7 \\
19.2\end{array}$ & $\begin{array}{r}4 \\
8 \\
9 \\
9 \\
8 \\
6 \\
10 \\
5 \\
7 \\
7 \\
14 \\
15 \\
7 \\
20 \\
8 \\
12 \\
19\end{array}$ & $\begin{array}{l}4 \cdot 8 \\
2.4 \\
2.2 \\
2.3 \\
2 \cdot 7 \\
3.8 \\
2.4 \\
5.5 \\
4 \cdot 1 \\
4.5 \\
2.3 \\
2.2 \\
4.8 \\
1 \cdot 8 \\
5.1 \\
3.6 \\
2.8\end{array}$ & $\begin{array}{l}130 \\
150 \\
170 \\
140 \\
130 \\
130 \\
110 \\
165 \\
140 \\
150 \\
120 \\
140 \\
130 \\
190 \\
180 \\
120 \\
140\end{array}$ & $\begin{array}{r}80 \\
85 \\
100 \\
90 \\
80 \\
80 \\
60 \\
90 \\
95 \\
90 \\
75 \\
90 \\
90 \\
130 \\
110 \\
85 \\
80\end{array}$ & $\begin{array}{l}1.0 \\
0.9 \\
0.95 \\
1.2 \\
0.6 \\
0.85 \\
0.7 \\
0.8 \\
0.9 \\
0.9 \\
0.6 \\
0.9 \\
1.2 \\
0.8 \\
1.0 \\
0.5 \\
0.9\end{array}$ & $\begin{array}{r}82 \\
64 \\
68 \\
61 \\
100 \\
106 \\
111 \\
119 \\
104 \\
40 \\
124 \\
57 \\
55 \\
74 \\
71 \\
113 \\
75\end{array}$ & $\begin{array}{r}45 \\
475 \\
149 \\
38 \\
230 \\
42 \\
101 \\
38 \\
20 \\
210 \\
24 \\
189 \\
53 \\
182 \\
1,340 \\
364 \\
134\end{array}$ \\
\hline
\end{tabular}

Male patients.

endogenous creatinine clearance-uncorrected, corrected for surface area, and expressed as an age-related percentage-on the one hand and the total dose, period of ingestion, and average rate of ingestion of aspirin on the other. None of the correlations was significant $(P>0 \cdot 1$ in all cases; table II).

The results of the renal function tests of those patients who were investigated on two occasions are shown in table III. They were divided into two groups-those who had continued taking aspirin and those who had not. In each group the plasma creatinine and creatinine clearance results (uncorrected) were compared within the group, using a paired $t$ test. The change within one group was then compared with the change in the other group, using a $t$ test (table IV). There were no significant differences within the groups or between groups.

TABLE II-Correlation between Aspirin Intake and Renal Function. Results expressed as Correlation Coefficients

\begin{tabular}{|c|c|c|c|c|c|}
\hline & & \multirow{2}{*}{$\begin{array}{c}\text { Plasma } \\
\text { Creatinine }\end{array}$} & \multicolumn{3}{|c|}{ Creatinine Clearance } \\
\hline & & & Uncorrected & Corrected & Age-related \\
\hline $\begin{array}{ll}\text { Total dose } \\
\text { Duration } \\
\text { Average dose }\end{array}$ & $\begin{array}{l}. \\
\cdots \\
\cdots\end{array}$ & $\begin{array}{l}-0.154 \\
-0.270 \\
+0.246\end{array}$ & $\begin{array}{l}-0.036 \\
-0.064 \\
+0.080\end{array}$ & $\begin{array}{l}-0.039 \\
-0.060 \\
+0.048\end{array}$ & $\begin{array}{l}-0.004 \\
-0.070 \\
+0.134\end{array}$ \\
\hline
\end{tabular}

The skew distribution of the white cell excretion rates rendered them unsuitable for a $t$ test so a non-parametric analysis was used. A Wilcoxon matched-pairs signed rank test was used to compare the changes in leucocyturia within each group. No signiticant change was found (continued aspirin,
TABLE IV-Analysis of Changes in Renal Function of Two Groups of Patient after Two Years

\begin{tabular}{|c|c|c|c|}
\hline & \multicolumn{2}{|c|}{$t$-Test } & \multirow{2}{*}{$\mathbf{P}$} \\
\hline & $\begin{array}{c}\text { Within-Group } \\
\text { Comparison }\end{array}$ & $\begin{array}{c}\text { Between-Group } \\
\text { Comparison }\end{array}$ & \\
\hline $\begin{array}{l}\text { Plasma creatinine: } \\
\text { Patients who continued aspirin } \\
\text { Patients who discontinued aspirin }\end{array}$ & $\begin{array}{l}1.513 \\
1.759\end{array}$ & 0.194 & $>0.8$ \\
\hline $\begin{array}{l}\text { Uncorrected creatinine clearance: } \\
\text { Patients who continued aspirin } \\
\text { Patients who discontinued aspirin }\end{array}$ & $\begin{array}{l}0.093 \\
0.094\end{array}$ & 0.049 & $>0.8$ \\
\hline
\end{tabular}

$T-8$; discontinued aspirin, $T-4 ; P>0 \cdot 1)$. A Mann-Whitney $\mathrm{U}$ test was used to compare the groups and again there was no significant difference $(U=23 ; P>0 \cdot 3)$.

None of our patients had a history of renal colic. None had more than a trace of proteinuria. Three had white cell excretion rates above the upper limit of normal suggested by Little (1962) of 574,000 per hour. White cell excretion rate did not correlate with other tests of renal function or aspirin intake. The results of the five intravenous pyelograms (in cases $2,4,6,10$, and 13) were all normal.

\section{Discussion}

None of our patients had clinically important impairment of renal function and there was no significant change in function during the two years of continuing aspirin ingestion. The slight reductions in creatinine clearance, even after correction for size

rable III-Aspirin Consumption and Results of Renal Function Tests before and after a Two-year Interval in 14 Patients with Rheumatoid Arthritis

\begin{tabular}{|c|c|c|c|c|c|c|c|c|c|}
\hline \multirow[t]{2}{*}{$\begin{array}{l}\text { Case } \\
\text { No. }\end{array}$} & \multicolumn{2}{|c|}{ Aspirin Consumption } & \multirow[t]{2}{*}{$\begin{array}{c}\text { Extra Aspirin } \\
\text { Between Tests } \\
(\mathbf{k g})\end{array}$} & \multicolumn{2}{|c|}{$\begin{array}{c}\text { Plasma Creatinine } \\
(\mathbf{m g} / 100 \mathrm{ml})\end{array}$} & \multicolumn{2}{|c|}{$\begin{array}{c}\text { Uncorrected } \\
\text { Creatinine Clearance } \\
(\mathrm{ml} / \mathrm{min})\end{array}$} & \multicolumn{2}{|c|}{$\begin{array}{l}\text { W.B.C. Excretion } \\
\left(\times 10^{3} / \mathrm{hr}\right)\end{array}$} \\
\hline & 1st Test & 2nd Test & & 1st Test & 2nd Test & 1st Test & 2nd Test & 1st Test & 2nd Test \\
\hline \multicolumn{10}{|c|}{ Patients who Continued to take Aspirin during Interval } \\
\hline $\begin{array}{l}2 \\
5 \\
11 \\
12 \\
13^{*} \\
15 \\
17\end{array}$ & $\begin{array}{r}5.5 \\
6.0 \\
9 \cdot 6 \\
10.5 \\
8.7 \\
12 \cdot 8 \\
17 \cdot 0\end{array}$ & $\begin{array}{r}7 \cdot 0 \\
8 \cdot 0 \\
11 \cdot 6 \\
12 \cdot 2 \\
12 \cdot 2 \\
14 \cdot 8 \\
19 \cdot 2\end{array}$ & $\begin{array}{l}1 \cdot 5 \\
2.0 \\
2 \cdot 0 \\
1.7 \\
3.5 \\
2.0 \\
2.2\end{array}$ & $\begin{array}{l}1.15 \\
0.7 \\
0.7 \\
0.8 \\
1.15 \\
1.25 \\
0.9\end{array}$ & $\begin{array}{l}0.9 \\
0.6 \\
0.6 \\
0.9 \\
1.2 \\
1.0 \\
0.9\end{array}$ & $\begin{array}{r}49 \\
110 \\
103 \\
64 \\
104 \\
52 \\
56\end{array}$ & $\begin{array}{r}59 \\
109 \\
115 \\
54 \\
61 \\
66 \\
78\end{array}$ & $\begin{array}{r}120 \\
570 \\
103 \\
50 \\
71 \\
720 \\
21\end{array}$ & $\begin{array}{r}475 \\
230 \\
24 \\
189 \\
53 \\
1,340 \\
134\end{array}$ \\
\hline \multicolumn{10}{|c|}{ Patients who did not continue to take Aspirin during Interval } \\
\hline $\begin{array}{c}1 \\
3 \\
4 \\
6^{*} \\
8 \\
10 \\
14\end{array}$ & $\begin{array}{r}7.0 \\
7.2 \\
7.6 \\
8.3 \\
10.0 \\
11.4 \\
13.0\end{array}$ & $\begin{array}{r}7.0 \\
7 \cdot 2 \\
7.6 \\
8 \cdot 3 \\
10.0 \\
11.4 \\
13.0\end{array}$ & $\begin{array}{l}\text { Nil } \\
\text { Nil } \\
\text { Nil } \\
\text { Nil } \\
\text { Nil } \\
\text { Nil } \\
\text { Nil }\end{array}$ & $\begin{array}{l}1 \cdot 0 \\
0.95 \\
1 \cdot 2 \\
0 \cdot 85 \\
0 \cdot 8 \\
0.9 \\
0.8\end{array}$ & $\begin{array}{l}0.8 \\
0.8 \\
0.9 \\
0.9 \\
0.7 \\
0.85 \\
0.9\end{array}$ & $\begin{array}{r}78 \\
55 \\
58 \\
103 \\
120 \\
37 \\
72\end{array}$ & $\begin{array}{r}92 \\
51 \\
76 \\
75 \\
115 \\
43 \\
70\end{array}$ & $\begin{array}{r}45 \\
149 \\
38 \\
42 \\
38 \\
210 \\
182\end{array}$ & $\begin{array}{r}74 \\
738 \\
729 \\
32 \\
132 \\
285 \\
117\end{array}$ \\
\hline
\end{tabular}

Male patients. 
and age, were not unexpected. Burry (1970) found a creatinine clearance below $80 \mathrm{ml} / \mathrm{min}$ in 49 out of 97 unselected patients with rheumatoid arthritis and he showed a correlation between reduction in glomerular filtration rate and severity of articular erosions on radiographs. All our patients had radiological evidence of severe rheumatoid arthritis. There is no accepted renal lesion of rheumatoid arthritis, however, so these observed depressions of filtration rate may reflect early involvement of the kidneys by amyloidosis, glomerulonephritis, or analgesic nephropathy. None of our patients had features of amyloidosis or glomerulonephritis but these cannot be totally excluded without renal biopsy, which in our cases was not justified. Equally, we cannot exclude the possibility that some had very early analgesic nephropathy. Nevertheless, our inability to show any correlation between aspirin dose and renal function and the absence of any significant decline in function with continuing aspirin intake are against this suggestion. Bulger et al. (1968) studied 42 patients who had taken an average of $8.4 \mathrm{~kg}$ of aspirin without phenacetin (except in two patients) and found some correlation between depression of creatinine clearance and total dose of aspirin. Their clearances were not corrected for age, however, and the patients with depressed renal function were slightly older, had a longer duration of arthritis, and a stronger history of receiving other nephrotoxic drugs (notably gold salts) than those with normal renal function. Moreover, none of their patients had a creatinine clearance below $50 \mathrm{ml} / \mathrm{min}$ in spite of an aspirin intake of up to $40 \mathrm{~kg}$.

The obvious conclusion from our study and that of Bulger et al. (1968) is that aspirin given alone in the doses commonly prescribed for rheumatoid arthritis rarely if ever causes serious renal disease. There is, however, an objection to such point-intime studies. Possibly analgesic nephropathy affects only a small minority of the population who are unduly sensitive because of slow hepatic inactivation of the causative drug or some other factor. Such patients would be eliminated from the rheumatology clinic by early death from analgesic nephropathy and would be under-represented in a cross sectional study. As a partial check on the possibility that Newcastle patients are dying early from aspirin nephropathy we examined the case notes of all patients who had died in the Royal Victoria Infirmary in the last five years with a clinical or pathological diagnosis of both rheumatoid arthritis and renal failure. There is a high probability that any patient attending our rheumatology clinic who had died in hospital would have done so in the Royal Victoria Infirmary. Of the six patients who met these criteria only one had analgesic nephropathy; he had consumed between 3 and $6 \mathrm{~kg}$ of phenacetin as Sonalgin. One patient had died in uraemia without a primary diagnosis. There was no necropsy, but there was no history of heavy analgesic intake. The four other patients had firm pathological evidence of unrelated renal disease. Ideally this evidence for the lack of aspirin nephrotoxicity should be tested by a prospective trial of aspirin takers as planned in New Zealand (Wigley, 1971). Decades of observation will probably be needed, however, to provide a firm answer in a population of 3 million.

It would be unsafe to extrapolate our results to patients taking aspirin in drug mixtures, in climates hotter than those of England or the State of Washington (Bulger et al., 1968), or in the very high dosage (up to $30 \mathrm{~g} /$ day) sometimes adopted by drug habitues (Kincaid-Smith et al., 1971). So far as they go, however, our results contradict the growing belief that aspirin is the most nephrotoxic of the common analgesics. The following evidence has been given for this belief.

Firstly, animal studies, reviewed by Nanra et al. (1971), which suggested that aspirin, alone or in combination with phenacetin, is more nephrotoxic than phenacetin alone. Though important these studies can be applied to man only with great reserve.

Secondly, the occurrence of analgesic nephropathy in seven patients who gave no history of taking phenacetin and whose major drug consumption was of aspirin (Harvald, 1963; Lawson and MacLean, 1966; Olaffson et al., 1966; Prescott, 1969;
Murray et al., 1971). An eighth case was withdrawn after the discovery of methaemoglobinaemia (A. A. H. Lawson, personal communication to J. T. Scott). These cases have to be set against the massive international consumption of aspirin, which, unlike phenacetin, is often prescribed alone; against the far more numerous cases associated with phenacetin; and against the formidable difficulty of excluding forgotten drug consumption. It must be admitted, however, that drug abusers usually choose drug mixtures (Murray, $1972 \mathrm{~b}$ ).

Thirdly, the high incidence of papillary necrosis at necropsy in rheumatoid patients at certain centres. Papillary necrosis was found in 17 consecutive necropsies by Nanra and colleagues $(1970,1971)$ and aspirin was blamed by implication. The drug histories of these 17 patients have never been published, however, and the high incidence of papillary necrosis has been reported only from centres where aspirin-phenacetin mixtures have been popular (Clausen and Pedersen, 1961; Lawson and MacLean, 1966; Nanra et al., 1971). The disease is relatively rare in Newcastle and the State of Washington (Bulger et al., 1968) where rheumatologists have never been in the habit of prescribing such mixtures. The differences may have other explanations but climate is unlikely to enter into a contrast between Edinburgh and Newcastle.

Lastly, relapses in patients with analgesic nephropathy when they consumed aspirin-containing mixtures without phenacetin (Kincaid-Smith et al., 1971; Murray et al., 1971). Such reports are not easy to evaluate. In all the six cases reported in detail by Kincaid-Smith et al. (1971) the deterioration in renal function was associated with urinary obstruction by sloughed papillae; this might have been a sign of renewed activity of the disease but it is also an accident that could have occurred in the absence of analgesic intake.

We conclude that the case against aspirin is very weak and that there is no need to restrict its sale on the basis of nephrotoxicity. Is there indeed any need to restrict the sale of any analgesic? The studies of S $\phi$ rensen (1966), Lawson (1973), and Waters et al. (1973) which showed a low prevalence of renal disease in subjects who had consumed several kilograms of analgesic mixtures-usually containing both aspirin and phenacetin-suggest that there is not. These mixtures, however, do play a key role in analgesic abuse (Murray and Smith, 1972), possibly because of the uplift provided by other ingredients such as caffeine. It would seem reasonable to provide at least a "Government health warning" on each packet (Bishop et al., 1972).

We still feel that the most likely culprit in analgesic nephropathy is phenacetin. Since it is so rarely consumed alone direct prospective studies of its role are impracticable and it must be judged on indirect evidence. In view of the encouraging results from Scandinavia (Nordenfelt, 1972) and South-west Scotland (Murray, 1972 a) a national experiment on a larger scale on its restriction seems to us justifiable and we would welcome moves to limit its sale to "prescription only" in Britain, provided we can first arrange adequate data collection to ensure that the experiment really gives an answer.

We thank Professor David Newell and his colleagues in the Department of Medical Statistics for help with the analysis of the results and Dr. Rosalind Ashcroft and her staff in the renal laboratory for help with the biochemical investigations.

\section{References}

Abel, J. A. (1971). Clinical Pharmacology and Therapeutics, 12, 583.
Bell, D., Kerr, D. N. S., Swinney, J., and Yeates, W. K. (1969). British Medical fournal, 3, 378.

Bengsston, U. (1969). Lancet, 1, 264.

Bishop, J., Znamirowska, M. I., and Meltzer, A. S. (1972). Canadian Medical Association fournal, $107,758$.

British Medical fournal (1965). 1, 673.

British Medical Fournal. (1970). 4, 125. matic Diseases, 27, 339. 
Burry, A. F. (1970). Paper presented to the Heberden Society.

Burry, A. F. (1971). In Renal Infection and Renal Scarring, ed. P. KincaidSmith and K. F. Fairley, p. 335. Melbourne, Mercedes.

Calder, I. C., Funder, C. C., Green, C. R., Ham, K. N., and Tange, J. D. (1971). British Medical fournal, 4, 518 .

Calder, I. C., Funder, C. C., Green, C. R., Ham, K. N., and Tange, J. D. (1972). British Medical fournal, 1, 152.

Clarkson, A. R., and Lawrence, J. R. (1971). In Renal Infection and Renal Scarring, ed. P. Kincaid-Smith and K. F. Fairley, p. 375. Melbourne, Mercedes.

Clausen, E., and Pedersen, J. (1961). Acta Medica Scandinavica, 170, 631.

Cove-Smith, J. R., and Knapp, M. S. (1973). Lancet, 2, 70.

Dubach, U. C. (1971). Deutsche Medizinische Wochenschrift, 96, 303.

Gault, M. H. (1972). Canadian Medical Association fournal, 107, 756.

Gault, M. H., Blennerhassett, J., and Muehrcke, R. C. (1971). American fournal of Medicine, 51, 740.

Gault, M. H., Rudwal, T. C., Engles, D. W., and Dossetor, J. B. (1968). Annals of Internal Medicine, 68, 906.

Gilman, A. (1964). American fournal of Medicine, 36, 167.

Hart, F. D., Taylor, R. T., Huskisson, E. C., and Shenfield, G. M. (1970). British Medical fournal, 4, 363.

Harvald, B. (1963). American fournal of Medicine, 35, 481.

Kincaid-Smith, P. (1970 a). British Medical fournal, 4, 618

Kincaid-Smith, P. (1970 b). Prescribers' fournal, 10, 8.

Kincaid-Smith, P., Nanra, R. S., and Fairley, K. F. (1971). In Renal Infection and Renal Scarring, ed. P. Kincaid-Smith and K. F. Fairley, p. 385. Melbourne, Mercedes.

Kingsiey, D. P. E., et al. (1972). British Medical Fournal, 4, 656.

Koutsaimanis, K. G., and de Wardener, H. E. (1970). British Medical Fournal, 4, 131.

Lawson, A. A. H., and MacLean, N. (1966). Annals of the Rheumatic Diseases, 25,441 .

Lawson, D. H. (1973). Fournal of Chronic Diseases, 26, 39.

Linton, A. L. (1972). Canadian Medical Association fournal, 107, 749.

Little, P. J. (1962). Lancet, 1, 1149.
Murray, R. M. (1972 a). British Medical fournal, 4, 131.

Murray, R. M. (1972 b). Scottish Medical fournal, 17, 393.

Murray, R. M., Lawson, D. H., and Linton, A. L. (1971). British Medical Fournal, $1,479$.

Murray, R. M., and Smith, R. (1972). Lancet, 1, 73.

Nanra, R. S., and Kincaid-Smith, P. (1970). British Medical fournal, 3, 559.

Nanra, R. S., Chirawong, P., and Kincaid-Smith, P. (1971). In Renal Infection and Renal Scarring, ed. P. Kincaid-Smith and K. F. Fairley, p. 347. Melbourne, Mercedes.

Nanra, R. S., et al. (1970). Medical fournal of Australia, 1, 293.

Nordenfelt, O. (1972). Acta Medica Scandinavica, 191, 11 .

Olaffson, O., Gudmundsson, K. R., and Brekkan, A. (1966). Acta Medica Scandinavica, 179, 121 .

Prescott, L. F. (1969). Scottish Medical fournal, 14, 82.

Prescott, L. F. (1970). British Medical fournal, 4, 493.

Prescott, L. F. (1971). In Renal Infection and Renal Scarring, ed. P. KincaidSmith and K. F. Fairley, p. 421. Melbourne, Mercedes.

Raaflaub, J., and Dubach, U. C. (1969). Klinische Wochenschrift, 47, 1286.

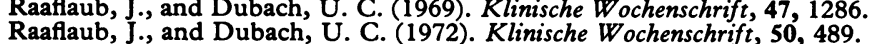

Ropes, M. W., Bennett, G. A., Cobb, S., Jacox, R., and Jessar, R. A. (1959). Bulletin of the Rheumatic Diseases, $9,175$.

Saker, B. M., and Kincaid-Smith, P. (1969). British Medical fournal, 1, 161.

Sanerkin, N. G. (1971). British Medical Fournal, 2, 223.

Scott, J. T. (1966). American Heart fournal, 71, 715.

Shelley, J. H. (1967). Clinical Pharmacology and Therapeutics, 8, 427.

Sórensen, A. W. S. (1966). Nephron, 3, 366.

Spühler, O., and Zollinger, H. U. (1953). Zeitzschrift für klinische Medizin, 151,1 .

de Wardener, H. E., and Koutsaimanis, K. G. (1971). British Medical Fournal, 2, 45 .

Waters, W. E., Elwood, P. C., and Asscher, A. W. (1973). Lancet, 1, 341.

Wesson, L. G. (1969). Physiology of the Human Kidney, p. 97. New York, Grune and Stratton.

Wigley, R. D. (1971). New Zealand Medical fournal, 74, 301.

Wilson, D. R. (1972). Canadian Medical Association fournal, 107, 752.

\title{
Ventilation-Perfusion Lung Scanning for Pulmonary Emboli
}

\author{
OLWEN WILLIAMS, JAMES LYALL, MARIAN VERNON, D. N. CROFT
}

British Medical Fournal, 1974, 1, 600-602

\section{Summary}

The conventional method of lung scanning detects defects of pulmonary artery perfusion. False positive results occur because regions of hypoventilation, such as are present in obstructive airways disease, also cause defects of perfusion. The converse is not true, however, as defects of perfusion continue to be ventilated. Thus in pulmonary embolism ventilation-perfusion discrepancy (normal ventilation and impaired perfusion) occurs.

We have assessed the clinical value of this discrepancy. Out of 18 patients with ventilation-perfusion discrepancy 14 had a final diagnosis of pulmonary emboli, whereas in none of the 34 patients without the discrepancy was this final diagnosis made. We conclude that combined ventilationperfusion lung scanning distinguishes pulmonary emboli from other lung conditions such as asthma and bronchitis which cause impaired pulmonary perfusion. The false positive rate was only $4 \%$ overall and $7.7 \%$ in patients with perfusion defects.

\section{Introduction}

Lung perfusion scanning is of value in the diagnosis of pulmonary embolism and is a simple and safe screening proced-

Isotope Department, St. Thomas's Hospital, London SE1 7EH OLWEN WILLIAMS, M.sC., M.R.C.P., Senior Medical Registrar JAMES LYALL, M.SC., M.R.C.P., Lecturer in Medicine

MARIAN VERNON, B.SC., Physicist

D. N. CROFT, D.M., M.R.C.P., Consultant Physician ure. Interpretation of lung scans, however, creates a problem in some patients because abnormal perfusion is not peculiar to pulmonary embolism but can appear in a variety of lung diseases, including bronchitis and asthma (Lopez-Majano et al., 1966; Mishkin and Wagner, 1968). There is a need for a reliable method of diagnosing emboli in patients with asthma, bronchitis, and other conditions with impaired pulmonary perfusion.

Animal studies show that a reduction in lung ventilation such as occurs in man with chronic obstructive airways diseases leads rapidly to a corresponding reduction in lung perfusion. On the other hand, reduction in lung perfusion, as in pulmonary embolism, does not lead to a correspondingly marked and sustained reduction in ventilation. With this in mind several workers have suggested that combined ventilation-perfusion lung scans might aid more specific diagnosis of pulmonary embolism (De Nando et al., 1970; Farmelant and Trainor, 1971). Their studies were made on a total of 57 patients and the results justified a clinical trial with a larger series. We have therefore performed 100 combined ventilation-perfusion lung scans on patients with pulmonary problems and have assessed the results in relation to the final diagnosis.

\section{Patients and Methods}

The patients had been routinely referred by clinicians in the hospital. Both scans were performed at the same session, ventilation scanning always preceding perfusion scanning. The combined scans took 20 minutes. Perfusion images were obtained by using macroaggregated albumin (MAA) labelled with ${ }^{99 \mathrm{~m}} \mathrm{Tc}$. Gaseous ${ }^{133} \mathrm{Xe}$ was used for ventilation imaging. All the images were recorded on Polaroid film by means of a Nuclear Enterprises mark III gamma camera with a diverg- 